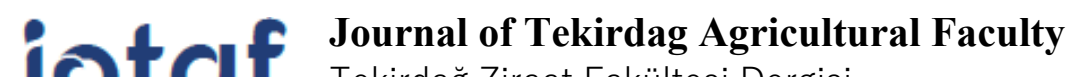 \\ Tekirdağ Ziraat Fakültesi Dergisi
}

\section{Empirical Modelling of Global Solar Radiation in Hatay (Turkey) Province}

Hatay (Türkiye) İli Küresel Güneş Radyasyonunun Ampirik Modellemesi

\author{
Recep KÜLC $\ddot{U}^{1 *}$, Rabia ERSAN ${ }^{2}$
}

\begin{abstract}
There are many models used in global solar radiation prediction. However, these prediction models vary according to the climate and geographic characteristics of the region involved. When the prediction model determined for a region is used in a different region, the prediction model may not work. In order to gain absolute and stable results from these models, the studies should be either custom-made or tested.

In this study, 7 different models were examined, comparison charts were created and statistical interpretations were made in order to determine the monthly average global solar radiation coming to the horizontal plane taking into account the climatic characteristics of Hatay province, located in the eastern $39.92^{\circ}$ latitude and northern longitude $36.16^{\circ}$, covering an area of $5403 \mathrm{~km}$, and has a humid climate with a value of 41.3 , based on De Martonne-Gottmann's drought index and 50.6 based on Erinç's rainfall efficiency index.

Under the scope of this study, the most ideal global solar radiation prediction model was selected by making a statistical evaluation according to the parameters of determination coefficient $\left(\mathrm{R}^{2}\right)$, mean percentage error (MPE), mean deviation error (MBE), root mean square error (RMSE).

A general assessment of the graphics and statistical parameters of the predictions obtained by using the models and the measured data has indicated Model 4 as the most successful model by an RMSE value of 0.17306 , and the least successful model was Model 3 by an RMSE value of 2.11851 .

When the models are interpreted according to the determination coefficient, it has been observed that other models are generally successful. However, this situation does not coincide with the comparison charts of the predicted and measured data. For this reason, it was seen that the determination coefficient was not sufficient in the statistical evaluation of the prediction models. In the interpretation of the models, it was observed that the interpretation of root mean square error, mean percentage error and mean deviation error values together gave more accurate results. In conclusion, it has been suggested that Model 4 should be preferred for the global solar radiation forecast of Hatay province.
\end{abstract}

Keywords: Solar energy, Solar radiation, Global solar radiation, Modelling, Hatay.

\footnotetext{
1*Sorumlu Yazar/Corresponding Author: Recep KÜLCÜ, Faculty of Agriculture, Department of Agricultural Machinery and Technologies Engineering, Isparta University of Applied Sciences, Isparta, Turkey. E-mail: recepkulcu@isparta.edu.tr (D) OrcID: 0000-0002-7185-6514

${ }^{2}$ Rabia ERSAN, Faculty of Agriculture, Department of Agricultural Machinery and Technologies Engineering, Isparta University of Applied Sciences, Isparta, Turkey. E-mail: rabiaersan@gmail.com DrcID: 0000-0003-1119-4894.

Atıf/Citation: KÜLCÜ, R., ERSAN, R. Empirical Modelling of Global Solar Radiation in Hatay (Turkey) Province. Tekirda ğ Ziraat Fakültesi Dergisi, 18 (3), 446456.

CBu çalışma Tekirdağ Namık Kemal Üniversitesi tarafından Creative Commons Lisansı (https://creativecommons.org/licenses/by-nc/4.0/) kapsamında yayınlanmıştır. Tekirdağ 2021
} 


\section{$\ddot{\mathbf{O} z}$}

Global güneş radyasyonu tahmininde kullanılan çok sayıda model bulunmaktadır. Ancak bu tahmin modelleri, kullanılan bölgenin iklim ve coğrafi özelliklerine göre değişkenlik göstermektedir. Bir bölge için belirlenen tahmin modeli farklı bir bölgede kullanıldığında başarılı tahminler verememektedir. Bu modellerden doğru sonuçlar alınabilmesi için çalışmaların bölgesel ölçekte test edilmesi, model katsayılarının hesaplanması ve bölgeye uygun modelin tespit edilmesi gerekmektedir.

Bu çalışmada, $5403 \mathrm{~km}$ yüzölçümüne sahip, $39.92^{\circ}$ kuzey enlemi ile $36.16^{\circ}$ doğu boylamında yer alan, Erinç'in yağış etkinlik indeksine göre 50.6 değeri, De Martonne-Gottmann kuraklık indisine göre 41.3 değeri ile nemli iklim özelliğine sahip Hatay ilinde yatay düzleme gelen aylık ortalama global güneş radyasyonunun tahmin edilebilmesi için 7 farklı model incelenmiş, karşılaştırma grafikleri oluşturulmuş ve istatistiksel parametreler doğrultusunda yorumlamaları yapılmıştır. Çalışma kapsamında modellerin, determinasyon katsayısı $\left(\mathrm{R}^{2}\right)$, ortalama yüzde hata (MPE), ortalama sapma hatası (MBE) ve ortalama karekök hatası (RMSE) parametrelerine göre istatistiksel değerlendirmeleri yapılarak, Hatay ili için global güneş radyasyonu değerlerini en doğru tahmin eden model belirlenmiştir.

Modeller kullanılarak elde edilen tahminler ve ölçülen gerçek verilerin grafikleri ve istatistiksel parametreler genel olarak değerlendirildiğinde; en başarılı modelin 0.17306 RMSE değeri ile Model 4, en düşük başarıdaki modelin 2.11851 RMSE değeri ile Model 3 olduğu görülmüştür.

Modeller determinasyon katsayısına göre yorumlandığında diğer modellerinde genel olarak başarılı olduğu görülmüsştür. Fakat bu durum tahmin edilen ve ölçülen verilere ait karşılaştırma grafikleri ile örtüşmemektedir. Bu nedenle tahmin modellerinin istatistiki olarak değerlendirilmesinde determinasyon katsayısının yeterli olmadığ 1 görülmüştür. Modellerin yorumlanmasında ortalama karekök hatası, ortalama yüzde hata ve ortalama sapma hatası değerlerinin bir arada yorumlanması ile daha doğru sonuçlar verdiği belirlenmiştir.

Sonuç olarak Hatay ili global güneş radyasyonu tahmini için Model 4'ün tercih edilmesi önerilmiştir.

Anahtar Kelimeler: Güneş enerjisi, Güneş radyasyonu, Global güneş radyasyonu, Modelleme, Hatay 


\section{Introduction}

Reserves of energy and other resources are gradually decreasing with the increasing population of the earth. This situation directs us to sustainable and more efficient use of resources and reveals the importance of renewable resources. Solar energy is a low cost resource because of being both abundant and renewable as well as having no fuel cost. In addition to these, the fact that most of the environmental problems arising from the use of fossil fuels are not experienced in the production of solar energy makes this type of energy clean and environmentally friendly (Varınca and Gönüllü, 2006; Türkboyları, 2018; Türkboyları and Yüksel, 2021). The use of solar energy, which is seen as a natural and inexhaustible energy among all renewable resources, has become increasingly widespread in recent years. Academic studies conducted in the field of solar energy systems, the biggest energy source among renewable energy sources; are all concentrated towards the correct use of the potential and increasing its efficiency. Many commercial products are emerging in the field of solar energy due to the absence of environmental polluting wastes, simple applicability and the fact that no complex technology is required in thermal applications. Solar energy constitutes the basis of life on earth and is an abundant and clean resource. The sun is a natural fusion reactor that emits energy in the form of electromagnetic radiation into space (Karakaya et al., 2019). The basic input in solar energy systems is the amount of radiation from the sun. The amount of energy coming from the sun through the atmosphere is certain and it is approximately $1370 \mathrm{~W} / \mathrm{m}^{2}$. However, the amount of this value reaching earth varies between $0-1100 \mathrm{~W} / \mathrm{m}^{2}$ depending on climatic, atmospheric and topographic elements. Energy from the sun, due to atmospheric factors (dust, fog, mist, cloudiness, etc.), is partially absorbed by or changes direction in the atmosphere. The remaining part reaches the earth on different types of surface (e.g., soil, plant, bare land, water, artificial surface, etc.) and is absorbed again in different levels depending on the topography and texture while some is reflected back. Due to this complicated trip, the part of the radiation reaching the earth from outside of the atmosphere cannot be calculated precisely. In this context, prediction models developed by different researchers are being used.

The operating costs of solar energy systems are very low. In solar energy facilities, the main cost item is investment cost. The breakeven points and internal profitability ratios of these systems depend on the amount of energy generated, which is the sole revenue item of the facility. The main factor affecting the energy to be generated in solar energy facilities is the amount of global solar radiations. For this reason, feasibility studies are carried out before solar power plants are established. The success of the models that predict the global solar radiation is of great importance in order to perform feasibility studies in a healthy way.

Calculating the exact amount of global solar radiation is not only important for solar energy facilities but it is also important in terms of buildings to have heat loads for cooling purposes, evaluating passive building heating systems and examining the performance results, analyzing the operating performance of systems that provide solar energy collection and conversion. Thanks to the data obtained, it becomes easier to obtain optimum parameters in agriculture, use of water resources, detecting solar radiation behavior and defining architectural designs (Güngör et al., 2005).

There are many models used in global solar radiation prediction. However, these prediction models vary according to the climate and geographic characteristics of the region involved. When the prediction model determined for a region is used in a different region, the prediction model may not work. In order to gain absolute and stable results from these models, the studies should be either custom-made or tested (Kallioglu et al., 2017). Ertekin and Yaldız (1999) tried to estimate the monthly global solar radiation for Antalya province using the multiliner regression equation using combinations of each of nine variables, individually and together, including the extraterrestrial radiation, solar declination, mean relative humidity, ratio of sunshine duration, mean temperature, mean soil temperature, mean cloudiness, mean precipitation and mean evaporation. According to the results of this study, it was seen that the equation in which nine variables were used together had the highest $\mathrm{R}^{2}(0.99861)$, and the MPE (1.956) and RMSE (2.495) values were within acceptable ranges. Almorox et al. (2013) made estimation of daily global solar radiation from measured temperatures using Hargreaves-Samani model, Allen model, Samani model, Bristow-Campbell model, Almorox model and liner regression model in Canada de Luque, Cordoba, Argentina. In the results of this study, Samani model using the max-min temperature difference gave low $\mathrm{R}^{2}$ values when estimated with its own coefficients, but high $\mathrm{R}^{2}$ values when adapted to the region. This model had $\mathrm{R}^{2}$ of 0.887, RMSE of 2.046, MBE of -0.080 and MPE of -2.481 . 
Karakaya et al (2019) statistically compared the data of global solar radiation prediction models using 5 models, namely Veeren and Kumar, Cheegar and Chibani, Ampratwum and Dorvlo, Bahel, Luhanga and Andringa, in this study they conducted in the Şanliurfa region. They reported that the closest value to the measurement results was Cheegar and Chibani Model with a value of $0.9912 \mathrm{R}^{2}$. When Cheegar and Chibani Model were compared with real meteorological data, it was seen that the difference between the developed models was very small. Külcü et al. (2017), estimated global solar radiation on horizontal surfaces for Mersin city using 6 empirical models. Model $6\left(\frac{\mathrm{H}}{\mathrm{H}_{0}}=\left[\frac{1.333962\left(\frac{\mathrm{S}}{\mathrm{S}_{0}}\right)}{0.044188 \mathrm{w}_{\mathrm{s}}}\right]+0.002578 \mathrm{w}_{\mathrm{s}}\right)$ gave the most successful estimation (RMSE of 0.8576, MBE of -0.3251, MPE of-4.7622) among using models. Bulut and Büyükalaca (2007), the global solar radiation forecasts based on the trigonometric functions developed by modeling themselves had applied for Turkey's 68 provinces. According to the results of the study, Antakya was among the most successful provinces (RMSE of 2.91 and $\mathrm{R}^{2}$ of 0.90 ).

The purpose of this study is to test each one of the 7 different models in the literature and identify the model, along with all its values and coefficients, which can be applied under Hatay conditions to predict the global solar radiation amount of the province.

\section{Material and Methods}

It takes place in the sun belt as well as the geopolitical position of Turkey is of great importance in terms of having to climatic wealth. In this study, the amount of global solar radiation reaching Turkey's southernmost Hatay province, located in the eastern $39.92^{\circ}$ latitude and northern longitude $36.16^{\circ}$, covering an area of $5403 \mathrm{~km}$, has been tried to be predicted using meteorological data (Figure 1). With statistical interpretations, the ideal global solar radiation prediction model for Hatay province has been determined.

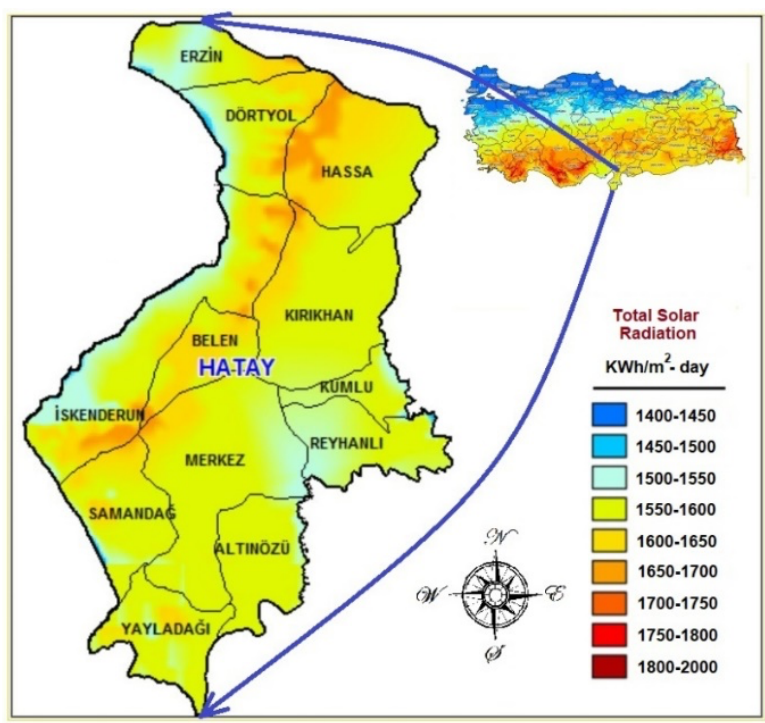

Figure 1. Hatay province solar energy potential spatial map (Anonymous 2020a)

Located in the south of our country, on the eastern shores of the Gulf of Iskenderun, at an altitude of $89 \mathrm{~m}$ above sea level, the province of Hatay has a warm and temperate climate. According to the values calculated by using the measurement data between the years 1940-2019, the region has a humid climate with a value of 41.3, based on De Martonne-Gottmann's drought index and 50.6 based on Erinç's rainfall efficiency index. It was observed that the highest temperature in the region was $44.6^{\circ} \mathrm{C}$ in July on 02.07 .2017 and the lowest temperature was in January with $11.8^{\circ} \mathrm{C}$ on 14.01 .1950 , according to the multi-year climate data of the General Directorate of Meteorology. Annual average sunshine duration is 86.2 hours (Anonymous, 2020b).

\subsection{Calculation of the amount of solar radiation coming out of the atmosphere in Hatay}

The amount of daily extra-terrestrial solar radiation calculated using Equations 1 and 2 (Duffie and Beckman, 2006; Mengec et al., 2006). 


$$
\begin{aligned}
& H_{O}=\frac{24 \times 3600 x G_{s c}}{\pi} f\left[\operatorname{Cos} \varphi \operatorname{Cos} \delta \sin w_{s}+\frac{\pi}{180} w_{S} \operatorname{Sin} \varphi \operatorname{Sin} \delta\right] \\
& f=1+0.033\left(\operatorname{Cos} \frac{360 n}{365}\right)
\end{aligned}
$$

Ho value is calculated using declination and clock angles. Declination angle refers to the angle between the plane on which the earth rotates around the sun and the equatorial axis. And this angle takes the maximum value on June 21, minimum value on December 21, and becomes zero on March 21 and September 21.

The angle of declination, which varies depending to the day of the year (as of January 1), was calculated using equation number 3 (Duffie and Beckman, 2006; Cooper, 1983).

$$
\delta=23.45 \operatorname{Sin}\left(360 \frac{n+284}{365}\right)
$$

The sunset hour angle refers to the angle between the expected sunray latitude (at sunset hour) and the calculated latitude. The sunset hour angle was calculated using Equation 4 (Ertekin et al., 2008).

$$
w_{s}=\arccos [-\tan (\varphi) \tan (\delta)]
$$

\subsection{Calculation of the global monthly average daily solar radiation in Hatay}

Models in the literature were used in calculating the solar radiation reaching the earth's surface in Hatay. In the models in the literature, S/S0 (Cloudiness coefficient) and clock angle (ws) coefficient are used as variables. Here, $\mathrm{S}$ refers to the sunshine duration of that day on the date and coordinate calculated, and S0 refers to the total day length in the same day and in the same place. While the $S$ value was determined according to meteorological measurements, the S0 value was calculated using equation number 5 (Duffie and Beckman, 2006).

$S_{0=\frac{2}{15}} \cosh ^{-1}-\tan \delta \tan \varphi$

\subsection{Models used in the study}

Within the scope of the study, seven different models in the literature were applied for the province of Hatay. These models were given in Table 1.

Table 1. Global solar radiation prediction models used in the study

\begin{tabular}{lc}
\hline Model No & \multicolumn{1}{c}{ Model } \\
\hline $\begin{array}{l}\text { Model } 1 \\
\text { (Angstrom, 1924; Presscott, 1940; Duffie and Beckman, 1980) }\end{array}$ & $\frac{\mathrm{H}}{\mathrm{H}_{0}}=\mathrm{c}_{1}+\mathrm{c}_{2}\left(\frac{\mathrm{S}}{\mathrm{S}_{0}}\right)$ \\
\hline $\begin{array}{l}\text { Model } 2 \\
\text { (Elagib and Mansell, 2000) }\end{array}$ & $\frac{\mathrm{H}}{\mathrm{H}_{0}}=\mathrm{c}_{1}+\mathrm{c}_{2}\left(\frac{\mathrm{S}}{\mathrm{S}_{0}}\right)$ \\
\hline $\begin{array}{l}\text { Model } 3 \\
\text { (El-Metwally, 2005) }\end{array}$ & $\frac{\mathrm{H}}{\mathrm{c}_{3}}=c_{1}(1 / \mathrm{S})$ \\
\hline $\begin{array}{l}\text { Model } 4 \\
\text { (Külcü, 2015) }\end{array}$ & $\frac{\mathrm{H}}{\mathrm{H}_{0}}=\left[\frac{\mathrm{c}_{1}\left(\frac{\mathrm{S}}{\mathrm{S}_{0}}\right)}{\mathrm{c}_{2} \mathrm{w}_{\mathrm{s}}}\right]+\mathrm{c}_{3} \mathrm{w}_{\mathrm{s}}$ \\
\hline $\begin{array}{l}\text { Model } 5 \\
\text { (Ampratwum and Dorvlo, 1999) }\end{array}$ & $\frac{\mathrm{H}}{\mathrm{H}_{0}}=\mathrm{c}_{1}+\mathrm{c}_{2}\left(\frac{\mathrm{S}}{\mathrm{S}_{0}}\right)+\mathrm{c}_{3} \log \left(\frac{\mathrm{S}}{\mathrm{S}_{0}}\right)$ \\
\hline $\begin{array}{l}\text { Model 6 } \\
\text { (Almorox and Hontoria, 2004) }\end{array}$ & $\frac{\mathrm{H}}{\mathrm{H}_{0}}=\mathrm{c}_{1}+\mathrm{c}_{2} \exp \left(\frac{\mathrm{S}}{\mathrm{S}_{0}}\right)$ \\
\hline $\begin{array}{l}\text { Model 7 } \\
\text { (Külcü, 2019) }\end{array}$ & $\frac{\mathrm{H}}{\mathrm{H}_{0}}=\mathrm{c}_{1}+\mathrm{c}_{2} \log \left(\frac{\mathrm{S}}{\mathrm{S}_{0}} / \mathrm{w}_{\mathrm{s}}\right)+\mathrm{c}_{3}\left(\frac{\mathrm{S}}{\mathrm{S}_{0}}\right)$ \\
\hline
\end{tabular}




\subsection{Statistical parameters used to test the prediction success of the models}

In order to compare the prediction capabilities of the models examined within the scope of the study; MPE (mean error percentage) in Equation 6, MBE (mean deviation error) in Equation 7, RMSE (root mean square error) in Equation 8 and $\mathrm{R}^{2}$ (Coefficient of determination) in Equation 9 have been calculated.

The coefficient of determination is an indicator of the interdependence between variables, and the closer this value is to one, the stronger the bond between variables. The root mean square error (RMSE) is the indicator of the deviation between the measured and calculated values and provides information about the short-term performance of the model under study. The closer the RMSE value is to zero, the better the performance of the model is evaluated. Mean deviation error (MBE) provides information about the long-term performance of the model under study. The closer the MBE value is to zero, the higher the model's performance. If this value is positive, it indicates that a prediction has been made above the calculated value, if it is negative, it indicates that a prediction has been made below the calculated value. Average error percentage (MPE) is an indication of the percentage value of the deviation between the measured and calculated values, and the closer the value to zero, the higher the performance of the model (Tırmıkçı, 2018).

$\mathrm{MPE}=\frac{1}{\mathrm{~N}} \sum_{\mathrm{i}=1}^{\mathrm{N}}\left(\frac{\mathrm{H}_{\mathrm{ip}}-\mathrm{H}_{\mathrm{io}}}{\mathrm{H}_{\mathrm{io}}}\right) \times 100$

$\operatorname{MBE}=\frac{1}{\mathrm{~N}} \sum_{\mathrm{i}=1}^{\mathrm{N}}\left(\mathrm{H}_{\mathrm{ip}}-\mathrm{H}_{\mathrm{io}}\right)$

$\operatorname{RMSE}=\sqrt{\frac{1}{\mathrm{~N}} \sum_{\mathrm{i}=1}^{\mathrm{N}}\left(\mathrm{H}_{\mathrm{ip}}-\mathrm{H}_{\mathrm{io}}\right)^{2}}$

$R^{2}=\frac{\sum_{i=1}^{N}\left(H_{i p}-H_{i p a}\right)\left(H_{i o}-H_{i o a}\right)}{\sqrt{\left[\sum_{i=1}^{N}\left(H_{i p}-H_{i p a}\right)^{2}\right]\left[\sum_{i=1}^{N}\left(H_{i o}-H_{i o a}\right)^{2}\right]}}$

\section{Results and Discussion}

The global radiation values predicted by the models used in the study and the monthly changes of the values measured from the meteorology station in the city of Hatay are shown in graphs.

Figure 2 shows the data measured with the values predicted by Model 1. According to the comparison of the forecast-measured data curve given in Model 1, the predicted values were found to be below the measured value in the period between the end of February and the middle of June. The prediction values in February and June gave the values closest to the measured value. In other months of the year, the predicted values were slightly above the measured value. Figure 3 shows the predicted values and measurement values indicated by Model 2. Model 2 has obtained the most accurate predictions throughout February, the last week of April, the first week of July, and the period from mid-September to December.

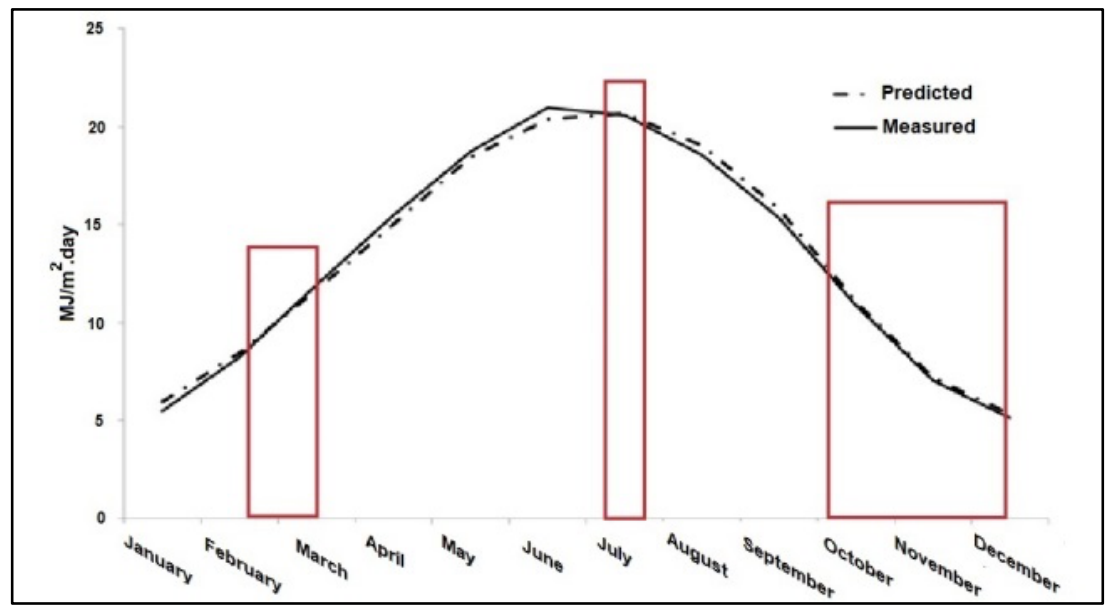

Figure 2. Data predicted and measured by model 1. 


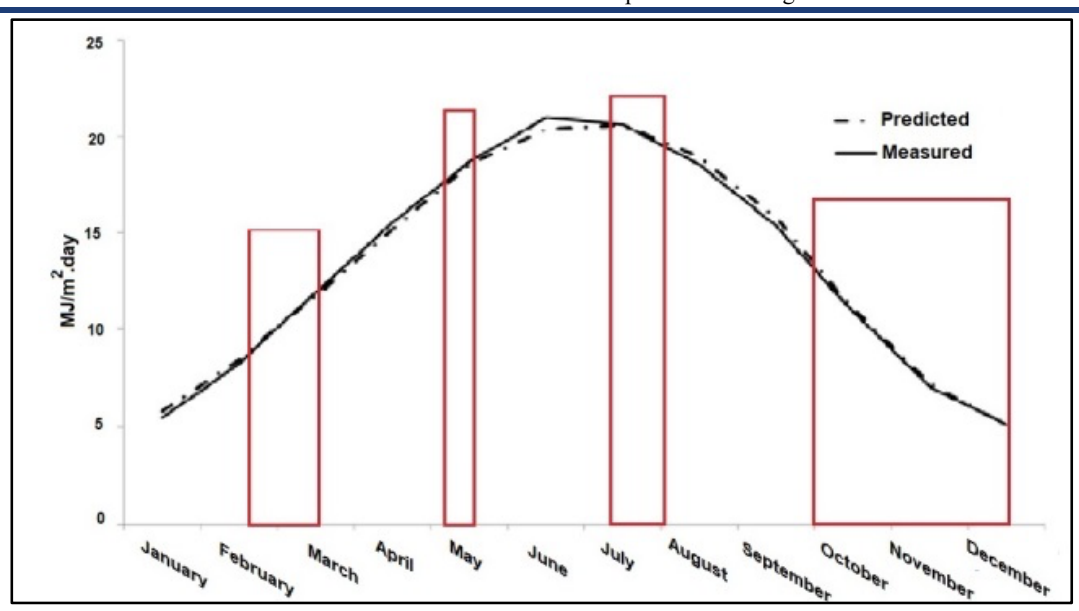

Figure 3. Data predicted and measured by model 2

The prediction values indicated by Model 3 are shown in Figure 4. Model 3 made the furthest predictions among all the models used within the scope of the study. Model 3 made predictions far from measured values, except for the last week of April and the end of September.

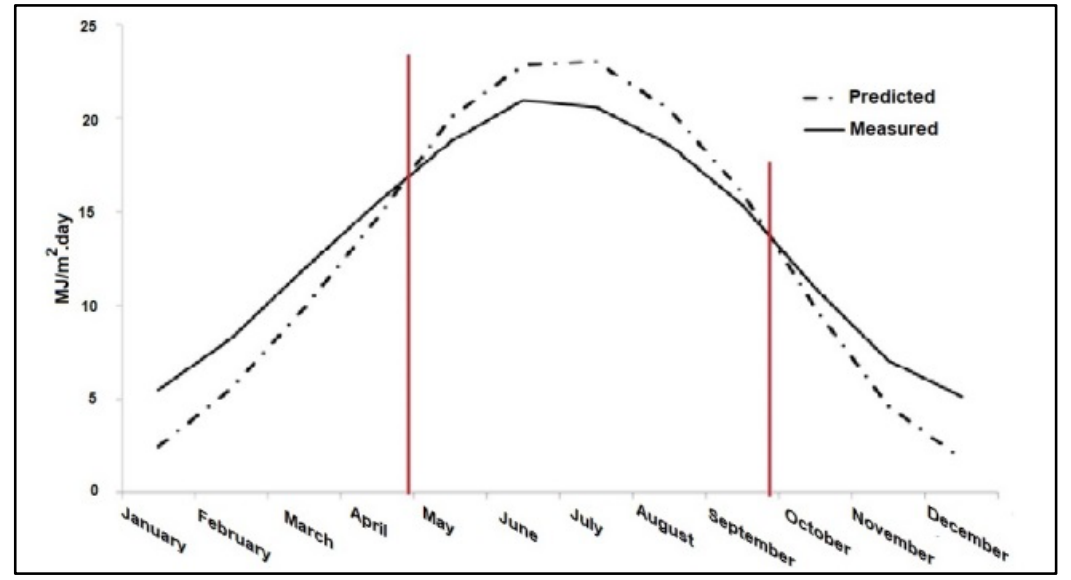

Figure 4. Data predicted and measured by model 3.

The prediction values achieved by using Model 4 are shown in Figure 5. Model 4 has made some very successful predictions. While it made lower predictions from the measurement values in January and June, it made higher predictions in other months of the year.

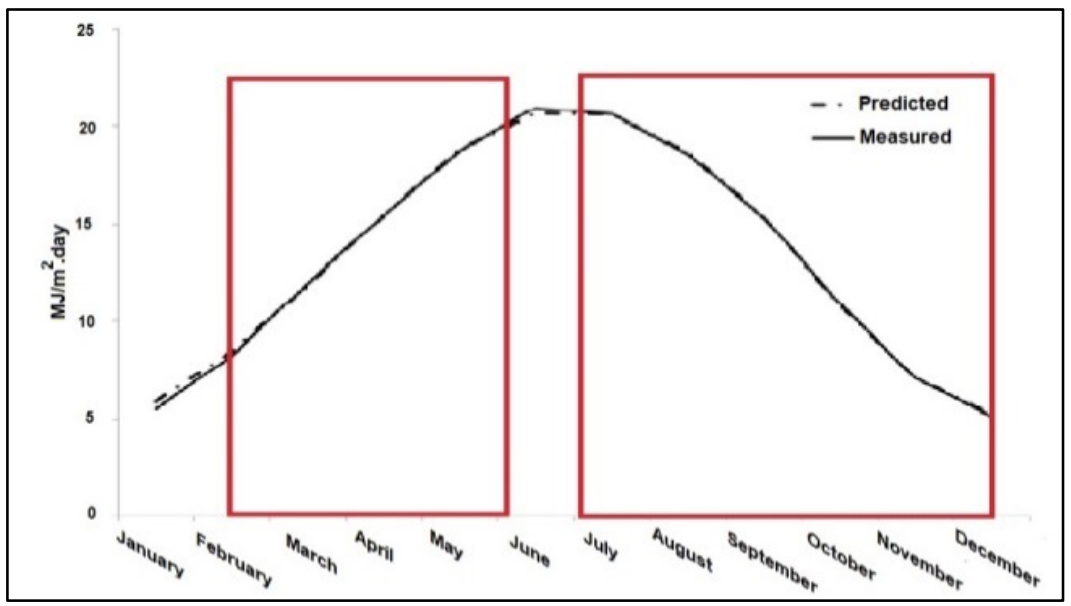

Figure 5. Data predicted and measured by model 4. 
Figure 6 shows the changes in predicted values achieved by Model 5. The predictions made by Model 5 are also very successful. The model obtained higher predictions between January 5 and May, from mid-July to the first week of August, and during October-December, with the furthest prediction being June.

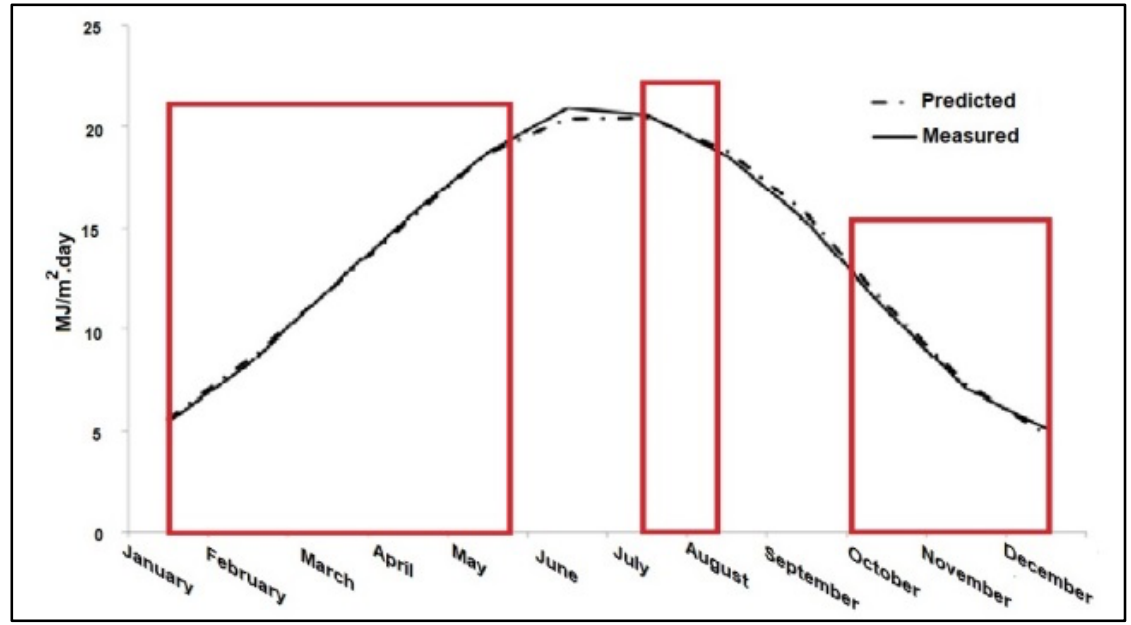

Figure 6. Data predicted and measured by model 5.

Global solar radiation values predicted by Model 6 are shown in Figure 7. In the forecasts made by Model 6, higher predictions were obtained in the period from the last week of February to mid-March, in the first week of July, and in the period from the last week of September to mid-November. And the predictions in other months were lower than the measurement values.

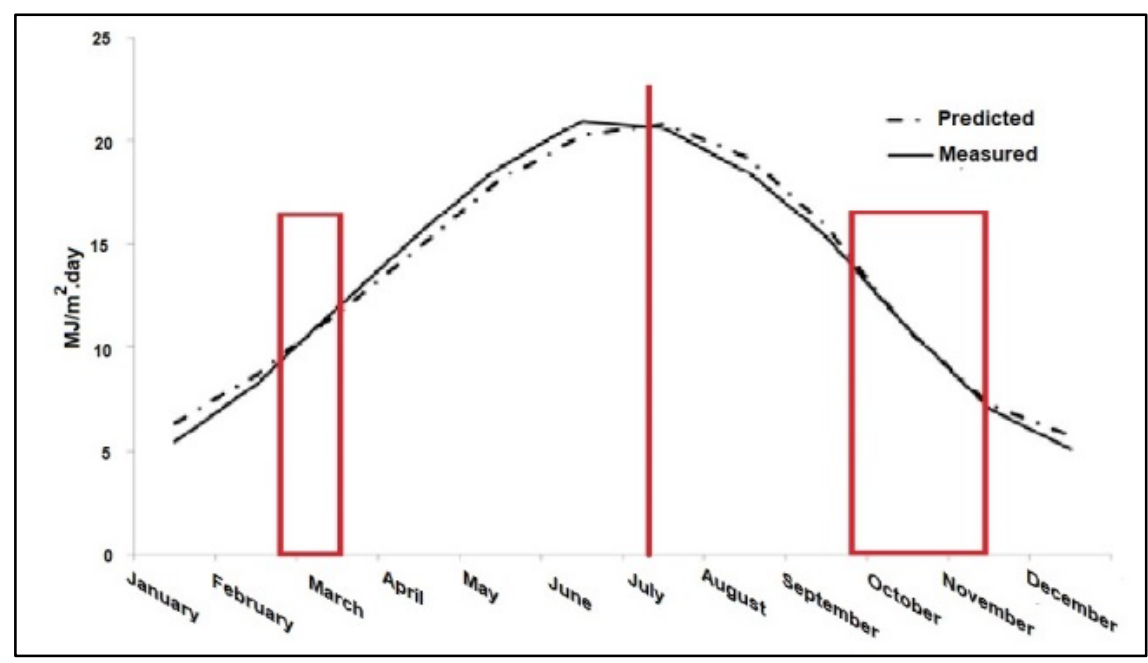

Figure 7. Data predicted and measured by model 6.

Figure 8 shows the changes of the predicted values achieved by Model 7. Predictions very close to the measured value were obtained in the period starting from mid-February and extending to mid-March, mid-May, in mid-July, and from late September to mid-December. 


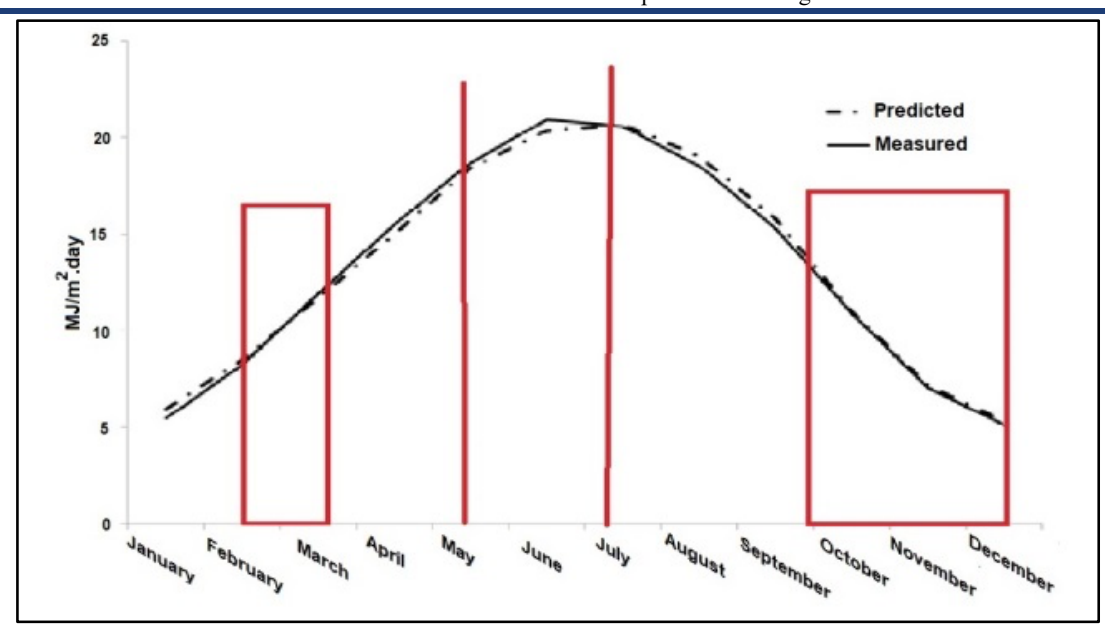

Figure 8. Data predicted and measured by model 7.

Table 2 shows the results of statistical analysis performed by using the predicted data and measured data of the models. The MBE parameter provides information about the long-term performance of the model. If this value gives negative values, it shows that it is below the prediction, and positive values show that it is above the prediction. The MPE parameter provides information about the average percentage deviation between the calculated and measured values. The RMSE parameter provides information about the short term performance of the models. The RMSE value is always positive and compares the actual deviation between the calculated values and the measured values for each term. The $\mathrm{R}^{2}$ parameter shows the importance of the relationship between calculated and measured values. If this value is close to 1, the relationship between the calculated and measured value is important, and the fact that it is far from 1 indicates that the level of importance is low. The c values in Table 2 represent the constants used in the models and are the results calculated to predict the global solar radiation levels of the province of Hatay within the scope of the study.

Table 2. Statistical analysis results of the models.

\begin{tabular}{cccccccc}
\hline & $\mathbf{c}_{1}$ & $\mathbf{c}_{2}$ & $\mathbf{c}_{3}$ & MPE & MBE & RMSE & $\mathbf{R}^{\mathbf{2}}$ \\
\hline Model 1 & 0.21619 & 0.35699 & - & 1.26822 & 0.05393 & 0.35727 & 0.99658 \\
Model 2 & 0.00000 & 0.55884 & 0.49341 & 0.87998 & 0.04295 & 0.29597 & 0.99761 \\
Model 3 & 0.00134 & - & - & -14.57251 & -0.59046 & 2.11851 & 0.99498 \\
Model 4 & 1.02219 & 0.04107 & 0.00295 & $\mathbf{0 . 8 0 4 9 0}$ & $\mathbf{0 . 0 3 5 6 8}$ & $\mathbf{0 . 1 7 3 0 6}$ & $\mathbf{0 . 9 9 9 3 1}$ \\
Model 5 & 0.58639 & 0.04302 & 0.54696 & 0.34448 & 0.02622 & 0.26443 & 0.99792 \\
Model 6 & 0.28767 & 0.03403 & - & 2.56235 & 0.09840 & 0.55411 & 0.99245 \\
Model 7 & 0.21619 & 0.00000 & 0.35699 & 1.26822 & 0.05394 & 0.35727 & 0.99658 \\
\hline
\end{tabular}

When the statistical evaluation parameters in Table 2 are examined; while the highest $\mathrm{R}^{2}$ value was calculated for Model 4 with a level of 0,99931 , the lowest $\mathrm{R}^{2}$ value was calculated for Model 6 with a level of 0.99245 . The $\mathrm{R}^{2}$ value of all the models was above 0.99 , and it was observed that the predicted data were in a very high relationship with the measured data. When the graphs of the predicted and measured data were examined, it was seen that the model closest to the measured value was Model 4, and the RMSE value was found to be lower than the other models with a value of 0.17306 . Model 4's MBE value was calculated at 0.03568 and MPE value at 0.80498 .

When the graphs of the predicted and measured data were examined, it was seen that the model furthest to the measured value was Model 3. The determination coefficient of this model was calculated to be 0.99498 , and this result showed that there was a strong relationship between variables. However, the RMSE (2.11851) value calculated for this model showed that the error level of the model was higher than the others. When the average deviation error of the model was examined, it was seen that it made predictions below the measured value with 
the value of -0.59046 and it was observed that the performance of the model was low with the average percentage error of -14.57251 .

Although the solar energy potential of the Hatay province on the average of Turkey, It causes a partial decrease in the amount of radiation because of it has low altitude in terms of topography, high amount of humidity and number of foggy days (Geçen, 2019). Due to this feature of region, it is thought that Model 4, which is based on cloudiness coefficient and time angle, is effective in giving more successful results for region. As a result of this study, when estimates made by Model 4 for the province of Hatay were compared with the literature data; It wass seen that the RMSE value of Model 4 was lower than other studies. The $\mathrm{R}^{2}$ value of Model 4 was also calculated higher than the studies in the literature. In addition, in the modeling study (Model 6 used by Kulcu) carried out by Külcü (2017), it was determined that the same model was also successful for Mersin.

\section{Conclusion}

Studies on global solar radiation prediction are based on the Angstrom-Prescott model or adaptation of other developed empirical models according to the spatial or climate characteristics of the region to be predicted and selecting the model that gives the most successful forecast. In this study, global solar radiation estimation of the region was made using 7 different empirical models according to the climate and geographic characteristics of Hatay province, and the most successful model was selected by evaluating the statistical results.

When the graphs of the data measured by using the predictions obtained by the models and the statistical parameters are evaluated in general, it is seen that the model that makes the closest prediction to the actual value is Model 4 with an RMSE value of 0.17306, and the model that makes the furthest prediction is Model 3 with an RMSE value of 2.11851. Other models are also found to be generally successful.

It has been observed that the determination coefficient was not sufficient in the statistical evaluation of the prediction models. It has also been observed that interpreting root mean square error values together with MPE and MBE values yields more accurate results. The same has also been observed in the comparison charts of predicted and measured data.

Regional and climatic characteristics such as geographical location, topographic structure, sunshine duration, cloudiness, temperature, precipitation, vapor pressure was used in solar forecast models. These parameters give different results in different regions. For this reason, it is recommended to work on more than one model in future studies and to validate the selected model for that region. It is thought that this study will be a guide in the planning phase of the studies to be carried out and the facilities to be established based on solar energy in the Hatay region. 


\section{References}

Almorox, J., Hontoria, C. (2004). Global solar radiation estimation using sunshine duration in Spain. Energy Conversion and Management 45: 152935 .

Almorox, J., Bocco, M. , Willington, E. (2013). Estimation of daily global solar radiation from measured temperatures at Cañada de Luque, Córdoba, Argentina. Renewable Energy, 60, 382-387.

Ampratwum, D.B., Dorvlo, A.S.S. (1999). Estimation of solar radiation from the number of sunshine hours. Applied Energy 63: 161-7.

Angstrom, A. (1924) Solar and terrestrial radiation. Report to the international commission for solar research on actinometric investigations of solar and atmospheric radiation. In: Quarterly Journal of the Royal Meteorological Society. 50(210):121-126.

Anonymous (2020a). https://www.enerjiatlasi.com/gunes-enerjisi-haritasi/hatay (Accessed date: 27 Eylül 2020)

Anonymous (2020b). https://mgm.gov.tr/veridegerlendirme/il-ve-ilceler-istatistik.aspx?m=HATAY (Accessed date: 27 Eylül 2020)

Bulut, H., Büyükalaca, O. (2007). Simple model for the generation of daily global solar-radiation data in Turkey. Applied Energy, 84(5), 477-491.

Cooper, P.I. (1983). The Absorption of radiation in solarstills. Solar Energy 12 (3): 333-346.

Duffie, J.A., Beckman, W.A. (1980). Solar engineering of thermal processes. Fourth Edition. New York: John Wiley\& Sons, 2013.

Duffie, J.A., Beckman, W.A. (2006). Solar engineering of thermal processes. 3rd ed. New York: John Wiley\& Son.

Elagib, N., Mansell, M.G. (2000). New approaches for estimating global solar radiation across Sudan. Energy Conversion and Management 41 (5): 419-434.

El-Metwally, M. (2005). Sunshine and global solar radiation estimation at different sites in Egypt. Journal of Atmospheric and Solar-Terrestrial Physics 67 (14): 1331-1342.

Ertekin, C., Yaldız, O. (1999). Estimation of monthly average daily global radiation on horizontal surface for Antalya (Turkey). Renewable Energy, $17(1), 95-102$.

Ertekin, C., Külcü, R., Evrendilek, F. (2008). Techno-Economic analysis of solar water heating systems in Turkey. Sensors 8 (2): $1252-1277$.

Geçen, R. (2019). Hatay ilinde güneş enerjisi potansiyeli ve güneş enerjisi santrali kurulacak alanlarının belirlenmesi. Social Sciences, 14(6), 30313054 .

Güngör, A., Abdullah, A.G., Kartal, Y. (2005). Ülkemiz enlemleri açık gün ışınımının Hesaplanması için bir algoritma, örnek uygulama: MERSİN. https://mmo.org.tr/sites/default/files/12a3c9878efeae8_ek.pdf (Accessed date: 27 Eylül 2020)

Kallioğlu, M.A., Ercan, U., Karakaya, H., Durmuş, A. (2017). Adıyaman ilinde yatay düzleme gelen global güneş 1şınım değerlerinin ampirik modeller ile geliştirilmesi. Fırat University, Journal of Engineering Sciences 29 (1): 151-159.

Karakaya, H., Avcı, A.S., Ercan, U., Kallioğlu, M.A. (2019). Şanlıurfa ilinde yatay yüzeye gelen anlık global güneş ışınımının modellenmesi. Dicle University Faculty of Engineering, Journal of Engineering 10 (1): 147-155.

Külcü, R. (2015). Isparta ili için yeryüzüne ulaşan güneş 1şınımının modellenmesi. Süleyman Demirel University, Journal of The Faculty of Agriculture 10(1): 19-26.

Kulcu, R., Suslu, A., Cihanalp, C., Yilmaz, D. (2017). Modelling of global solar radiation on horizontal surfaces for Mersin city. Wind Energy, 433(216), 127-4.

Külcü, R. (2019). Global güneş radyasyonunun ampirik modellenmesinde kullanılabilecek yeni bir modelin geliştirilmesi ve Çankırı ilinde uygulanması. Süleyman Demirel University, Yekarum e-Dergi 4 (2): 1-8.

Mengec, O., Ertekin, C., Sonmete, M.H. (2006). Evaluation of global solar radiation models for Konya, Turkey. Energy Conversion and Management 47 (18-19): 3149-3173.

Prescott, J. (1940). Evaporation from a water surface in relation to solar radiation. In: Transactions of the Royal Society of South Australia. 64(1):114118.

Tırmıkçı, C.A. (2018). İki eksen güneş izleyen hareketli güneş sistemi ve en uygun yıllık eğim açısı ile konumlandırılmış sabit güneşsisteminin gerçek zaman karşılaştırması. (Ph. D. Thesis) Sakarya University, Institute of Natural Sciences, Electrical and Electronics Engineering Department, Sakarya,Turkey

Türkboyları, E.Y. (2018). Tekirdağ Koşullarında Güneş Kolektörlerinden Elde Edilen Isı Enerjisi ile Sera Toprağının Dezenfekte Edilmesi, Journal of Tekirdag Agricultural Faculty, 15(1), pp. 123-128.

Türkboyları, E.Y., Yüksel, A.N. (2021). Use of Solar Panel System in Vermicompost (Worm Manure) Production Facilities as Source of Energy, Journal of Tekirdag Agricultural Faculty, 18(1), pp. 91-97.

Varınca, K.B., Gönüllü, M.T. (2006). Türkiye'de güneş enerjisi potansiyeli ve bu potansiyelin kullanım derecesi, yöntemi ve yaygınlığı üzerine bir araştırma. I. National Solar and Hydrogen Energy Congress, Eskişehir, pp. 270-275. 